[報文]

\title{
Identification of 2-Alkylcyclobutanones in Cashew Nut (Anacardium Occidentale)
}

\author{
Chen Susu $^{1)}$, Tsutsumi Tomoaki ${ }^{2)}$, Takatsuki Satoshi ${ }^{2)}$, Matsuda Rieko ${ }^{2)}$, \\ Kameya Hiromi $^{1)}$, Saito Kimie ${ }^{1)}$, Furuta Masakazu ${ }^{3)}$ and Todoriki Setsuko ${ }^{1) *}$ \\ ${ }^{1)}$ Food Safety Division, National Food Research Institute, 2-1-12, Kannondai, Tsukuba, Ibaraki 305-8642 Japan \\ ${ }^{2)}$ Division of foods, National Institute of Health Sciences, 1-18-1, Kamiyoga, Setagaya, Tokyo 158-8501 Japan \\ ${ }^{3)}$ Laboratory of Quantum-beam Chemical Biology, Radiation Research Center, Osaka Prefecture University, \\ 1-2, Gakuencho, Nakaku, Sakai, Osaka 599-8570 Japan
}

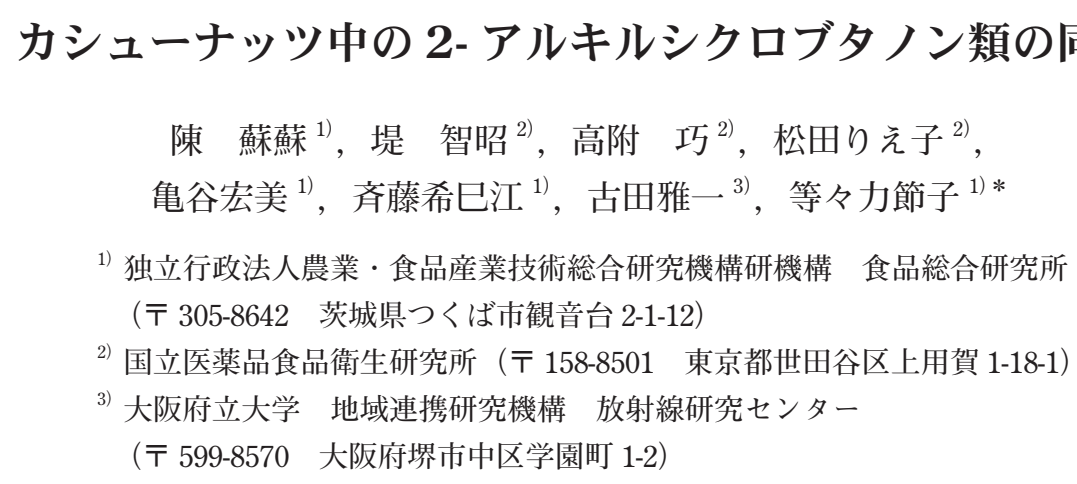

\begin{abstract}
Summary
The natural existence of the irradiation markers, namely, 2-dodecylcyclobutanone (2-dDCB), 2-tetradecenylcyclobutanone (2-tDeCB), and 2-tetradecylcyclobutanone (2-tDCB) in cashew nut (Anacardium occidentale) has recently been reported. In this study, 2-dDCB, 2-tDCB and 2-tDeCB were extracted from cashew nut of 2 different origins using supercritical fluid extraction (SFE). The irradiated samples were analysed by gas chromatography-mass spectrometry, whereas the non-irradiated samples were analysed with high-resolution gas chromatography-mass spectrometry (GC-HRMS). 2$\mathrm{dDCB}, 2-\mathrm{tDCB}$ and 2-tDeCB were detected and identified in the irradiated samples at $1 \mathrm{kGy}$ or greater. However, none of 2-ACBs was detected in the non-irradiated samples with GC-HRMS. The radioproduction yield of 2-alkylcyclobutanones (nmol/mmol precursor fatty acid/kGy) were 1.3, 1.3 and 1.7 for 2-dDCB, 2-tDCB and 2-tDeCB, respectively.
\end{abstract}

Key words: irradiation, 2-alkylcyclobutanone, cashew nut, detection method, GC-HRMS

\section{Introduction}

When fat-containing foods are irradiated, free

*連絡先 : setsuko@affrc.go.jp fatty acids and triacylglycerides in the foods are decomposed to 2-alkylcyclobutanones (2-ACBs). The 2ACBs have the same number of carbon atoms as the parent fatty acids from which they are formed, with an alkyl group located in ring position 2. These com- 
pounds are cyclic compounds formed by the loss of an electron from the oxygen on the carbonyl of fatty acids or triacylglycerides, followed by rearrangement to produce 2-ACBs specific to the parent fatty acids. In addition, 2-ACBs originate during irradiation but are not formed during the cooking, decay, or oxidation processes, indicating that they could function as unique radiolytic products (URPs) and be used as a detection marker for fat-containing foods and also to estimate the absorbed dose ${ }^{1)}$. Therefore, this 2-ACB method was adopted as a global standard by the European Committee for Normalization in 1996 (EN 1785) and declared a standard method in Japan in 2010. Thus far, this detection method has been successfully used a wide range of irradiated fat-containing foods, such as meat-based products ${ }^{2), 3)}$, cheeses ${ }^{4), 5)}$, eggs ${ }^{6)}$, exotic fruits ${ }^{7,8)}$, and seafood ${ }^{9}$.

However, the natural existence of 2-ACBs in nonirradiated nutmeg and cashew nut samples of India was reported, disproving the hypothesis that 2-ACBs are URPs ${ }^{10)}$. To date, only the Indian Group has reported the natural existence, and the need to improve analytical methods in order to resolve the emerging possibility that some non-irradiated foods may contain 2-ACBs has been emphasized ${ }^{11}$. In our previous paper, neither 2-DCB nor 2-dDCB was observed in any of the non-irradiated nutmeg samples by using GCHRMS analysis ${ }^{12}$. Therefore, the purpose of the present study was to investigate whether 2-dDCB, 2-tDCB and 2-tDeCB exist naturally in non-irradiated cashew nut samples and to determine the production efficacy of the 2-ACBs by irradiation treatment.

\section{Materials and Methods}

\section{Chemicals and food samples}

2-Cyclohexylcyclohexanone (2- $\mathrm{CHCH})$ as an internal standard for gas chromatography-mass spectrometry (GC-MS) was purchased from Wako Pure Chemical Industries, Ltd. (Osaka, Japan) and dissolved in $n$-hexane to produce a $0.1 \mu \mathrm{g} / \mathrm{mL}$ stock solution. The solution was preserved at $-20^{\circ} \mathrm{C}$. The 2-ACB standards, including 2-dDCB, 2-tDCB and 2tDeCB, which were synthesized by Hayashi Pure
Chemical Industries, Ltd. (Osaka, Japan) were equally mixed and diluted with $n$-hexane in a range of 0.02 $20.00 \mu \mathrm{g} / \mathrm{mL}$ for the running standards and spiking solution in recovery tests. Sodium sulphate anhydrous $\left(\mathrm{Na}_{2} \mathrm{SO}_{4}\right)$ was heated for $5 \mathrm{~h}$ at $600^{\circ} \mathrm{C}$ before use.

Cashew nut samples -2 lots from India (Lot A and Lot B) were purchased from Japanese nut makers. They were excised homogeneously with a food cutter and preserved at $-80^{\circ} \mathrm{C}$ before use.

\section{Irradiation system}

The ground cashew nut samples in aluminiumsealed polyethylene bags were irradiated with gamma rays from a cobalt 60 source (Gammacell 220; MDS Nordion International Co. Ltd., Ottawa, Ontario, Canada) at the National Food Research Institute of Japan. The dose rate was $5 \mathrm{kGy} / \mathrm{h}$. The samples were irradiated at doses of 1,5 and $10 \mathrm{kGy}$ at room temperature and were stored for 1 days at room temperature before analysis. An alanine pellet dosimeter (Bruker Biospin Ltd., Rheinstetten, Germany) was attached to the surface of each sample, and the absorbed dose was determined using an electron spin paramagnetic spectrophotometer (Bruker EMX; Bruker Biospin Ltd.). Non-irradiated cashew nut was used as a control and stored under the same conditions.

\section{Extraction of 2-ACBs}

The extraction of 2-ACBs from the cashew nut samples for GC-MS measurement was performed using a supercritical fluid extraction (SFE) system (Model SFX1220; Teledyne Isco, Inc., Lincoln, NE, USA) with carbon dioxide ${ }^{12)}$. A 1.5-g sample of ground cashew nut was homogenized with wet support (ratio of 1:1) in a mortar. A 5-mL SFE cartridge (i.d., 15 $\mathrm{mm}$; length, $56 \mathrm{~mm}$; Teledyne Isco, Inc.) was loaded with sand (about $2 \mathrm{~g}$ ), and then the cashew nut-wet support mixture was placed in the extractor. The sand protected the seal of the extraction cartridge. Four measurement samples were extracted for each lot. The blank control (with only wet support and sand), non-irradiated cashew nut samples, and irradiated cashew nut samples were prepared and analysed in the 
same way.

Extraction was carried out under the following conditions: pressure, $150 \mathrm{~atm}$; temperature, $80^{\circ} \mathrm{C} ; 5$ min static and 60 min dynamic with a $\mathrm{CO}_{2}$ flow rate of $2 \mathrm{~mL} / \mathrm{min}$. The 2-ACBs were trapped with $6 \mathrm{~mL} n$ hexane in a test tube (i.d., $13 \mathrm{~mm}$; length, $125 \mathrm{~mm}$ ). In this extraction process, $n$-hexane was added frequently to maintain the appropriate $n$-hexane amount. Finally, after dried with $\mathrm{NaSO}_{4}$ the cashew nut extract was concentrated to $5 \mathrm{~mL}$ under a stream of nitrogen at $40^{\circ} \mathrm{C}$ for cleanup.

\section{Cleanup of the extraction and preparation of samples}

About $1.0 \mathrm{~mL}$ of the cashew nut extract was added to a supelclean sulfoxide SPE cartridge column (3000 $\mathrm{mg} / 6 \mathrm{~mL}$; Supeluco, Bellefonte, PA, USA), which was conditioned with $10 \mathrm{~mL}$ acetone to remove residual moisture and equilibrated with $20 \mathrm{~mL} n$-hexane, after which a $4-14 \mathrm{~mL}$ fraction was collected with $n$-hexane. The flow rate was about $0.72 \mathrm{~mL} / \mathrm{min}$. Then, the eluted $n$-hexane was carefully concentrated to a volume of $1 \mathrm{~mL}$ in a rotary vacuum evaporator, further concentrated to near dryness under a stream of nitrogen at $40^{\circ} \mathrm{C}$, and then added to $0.2 \mathrm{~mL} 2-\mathrm{CHCH}(0.05$ $\mu \mathrm{g} / \mathrm{mL})$ as an internal standard. Finally, the mixture was transferred into a glass vial insert for GC-MS and high-resolution gas chromatography-mass spectrometry (GC-HRMS) analysis.

\section{GC-MS and GC-HRMS analysis of 2-ACBs}

Samples were analysed using a QP-2010 Plus model GC-MS system (Shimadzu, Kyoto, Japan) for irradiated samples and a JMS-700 MStation GC-HRMS system (JEOL Ltd., Tokyo, Japan) equipped with GC HP-6890 Plus (Agilent, Toronto, Ontario, Canada) for blank controls and non-irradiated samples. Data acquisition and control were performed using GC-MSSolution Ver. 2.53 SU3 software and DioK software (JEOL Ltd., Tokyo, Japan), respectively.

The GC conditions of the QP-2010 Plus model GC-MS system were as follows: column, DB-5MS (Agilent Technologies J \& W Scientific, USA) $60 \mathrm{~m}$ $\times 0.25 \mathrm{~mm}$ i.d., and $0.25-\mu \mathrm{m}$ film; column temperature program, $55^{\circ} \mathrm{C}(2 \mathrm{~min}), 55-175^{\circ} \mathrm{C}$ at $20^{\circ} \mathrm{C} / \mathrm{min}$, $175-250^{\circ} \mathrm{C}$ at $2^{\circ} \mathrm{C} / \mathrm{min}, 250-270^{\circ} \mathrm{C}$ at $10^{\circ} \mathrm{C} / \mathrm{min}, 270^{\circ} \mathrm{C}$ (5 min), $270-280^{\circ} \mathrm{C}$ at $10^{\circ} \mathrm{C} / \mathrm{min}$, and $280^{\circ} \mathrm{C}(10 \mathrm{~min})$; carrier gas, helium $1.00 \mathrm{~mL} / \mathrm{min}$; injection temperature, $250^{\circ} \mathrm{C}$; injection single taper inlet liner (SGE Analytical Science, Australia); injection mode, splitless; and injection volume, $1 \mu \mathrm{L}$. The $\mathrm{GC}$ conditions of the GC-HRMS were almost identical, but the injection volume was $2 \mu \mathrm{L}$.

The MS conditions of the QP-2010 Plus model GCMS system were as follows: ionization mode, electron ionization (EI); ion detection, selected ion monitoring (SIM); event time, $0.20 \mathrm{~s}$; detector voltage, $0.84 \mathrm{kV}$; ion source temperature, $200^{\circ} \mathrm{C}$; and interface temperature, $280^{\circ} \mathrm{C}$. The monitored ions were $m / z 98,95$ and 112 , and $m / z 98$ was selected for determination. The MS conditions of the GC-HRMS system were similar to those of the GC-MS system: ionization mode, EI; ion detection, SIM; resolution performance, 10000; ionization voltage, $70 \mathrm{eV}$; ionization current, $500 \mu \mathrm{A}$; ion source temperature, $230^{\circ} \mathrm{C}$; interface temperature, $280^{\circ} \mathrm{C}$; and event time, $2 \mathrm{cycle} / \mathrm{s}$. The monitored ions of $m / z$ 98.073, 95.086 and 112.088 were chosen, and 2-ACBs were identified with the area ratio of $\mathrm{m} / \mathrm{z}$ 112.088 to 98.073 according to EN 1785. Each sample was repeated at least 4 times.

\section{Determination fatty acid contents}

The fatty acid composition of cshew nut fat was performed by GC according to a previously reported method ${ }^{13), 14}$. In brief, Total lipids were extracted with chloroform/methanol and transesterification of fatty acids was performed by incubating the fats in anhydrous methanol containing $5 \% \mathrm{HCl}$ for $3 \mathrm{~h}$ at $100^{\circ} \mathrm{C}$. The methyl esters were analyzed on a GC-2014 (Shimadzu, Kyoto, Japan) with an FID and a capillary column. The data acquisition and control were conducted with GC-Solution Ver. 2.3 software. The GC conditions were as follows: column, DB-225 (Agilent Technologies J\&W Scientific, USA), $30 \mathrm{~m} \times 0.25 \mathrm{~mm}$ i.d., 0.25 $\mu \mathrm{m}$ film; column temperature program, $150^{\circ} \mathrm{C}$ (2 $\min ), 150-200^{\circ} \mathrm{C}$ at $2^{\circ} \mathrm{C} \min -1,200^{\circ} \mathrm{C}$ (43 min); carrier 
gas, helium, $1.00 \mathrm{~mL}$ min-1; injection temperature, $230^{\circ} \mathrm{C}$; injection volume, single taper inlet liner (SGE Analytical Science, Australia); injection mode, split at 30.0; injection volume, $1 \mu \mathrm{L}$. All determinations were performed at least 3 times.

\section{Statistical analysis}

Statistical tests were performed using Microsoft Office Standard 2007 Excel software (Microsoft Corporation, Redmond, WA, USA). Results were expressed as means \pm standard deviation for each determination.

\section{Results and Discussion}

\section{Fatty acid content}

The fatty acid composition of non-irradiation samples was evaluated by GC analysis. The list of the fatty acids present in cashew nut is shown in Table 1 . The total of fatty acids content in per gram of sample was $1.50 \pm 0.09 \mathrm{mmol} \mathrm{g}-1$. The oleic acid content was 0.97 $\pm 0.06 \mathrm{mmol} \mathrm{g}-1$, accounting for $63.6 \% \pm 0.2 \%$ of the fatty acid content, more than to any other fatty acid. The palmitic acid content was $0.14 \pm 0.009 \mathrm{mmol} \mathrm{g}-1$, accounting for $8.41 \% \pm 0.05 \%$ of all fatty acids. The stearic acid content was $0.12 \pm 0.007 \mathrm{mmol} \mathrm{g}-1$, accounting for $7.78 \% \pm 0.01 \%$ of all fatty acids.

Therefore, 2-tDeCB, 2-dDCB and 2-tDCB were chosen as the target 2-ACBs in this study as previous report ${ }^{10)}$.

\section{Detection of 2-ACBs from irradiated cashew nuts}

In the present study the condition of SFE was selected as previous report on nutmeg ${ }^{12)}$ and clean-up of the extract was performed with sulfoxide residue bonded silica stationary phase colmn ${ }^{15}$ ) because of its higher selectivity ${ }^{16)}$. This protocol was evaluated with recovery tests in which $2-\mathrm{dDCB}$ and 2-tDCB and 2 -tDeCB were spiked at $0.061 \mu \mathrm{g} / \mathrm{g}, 0.061 \mu \mathrm{g} / \mathrm{g}$ and $0.17 \mu \mathrm{g} / \mathrm{g}$ into control cashew nut samples and analysed with GC-MS $(n=4)$. The 2 -ACBs were not detected in the control samples. The recovery rates were $90 \% \pm 7 \%, 76 \% \pm 6 \%$ and $76 \% \pm 6 \%, 75 \% \pm 6 \%$ for 2-dDCB, 2-tDCB and 2-tDeCB, respectively, with mostly less than $10 \%$ relative standard deviation.

The typical chromatogram at $m / z 98$ of $1 \mathrm{kGy}$ irradated, un-irradiated sample was shown in Fig. 1. There were clear peaks in the retention times of 2-dDCB (27.81 $\pm 0.01 \mathrm{~min}), 2$-tDCB (36.13 \pm 0.01 $\mathrm{min}$ ), and 2-tDeCB (35.04 $\pm 0.01 \mathrm{~min})$ (a), which were the same as the pure standards (c); however, none of peaks was observed in the control sample (b). The signal-to-noise $(\mathrm{S} / \mathrm{N})$ ratio of each of these detected ions was greater than 3:1. The chromatograms and mass spectra of GC-MS analysis were clear enough to identify the presence of these 2 -ACBs according to the

Table 1 Fatty Acid content and composition of cashew nut (Lot A)

\begin{tabular}{|c|c|c|c|}
\hline \multicolumn{2}{|c|}{ Fatty Acid } & weigt $\%$ & mmole / g FW \\
\hline $\mathrm{C} 14: 0$ & Myristic Acid & - & \\
\hline $\mathrm{C} 16: 0$ & Palmitic Acid & $8.41 \pm 0.05$ & $0.141 \pm 0.009$ \\
\hline $\mathrm{C} 16: 1$ & Palmitoleic Acid & - & - \\
\hline C18:0 & Stearic Acid & $7.78 \pm 0.01$ & $0.118 \pm 0.007$ \\
\hline $\mathrm{C} 18: 1$ & Oleic Acid & $63.6 \pm 0.2$ & $0.973 \pm 0.057$ \\
\hline $\mathrm{C} 18: 2$ & Linoleic Acid & $16.9 \pm 0.04$ & $0.260 \pm 0.014$ \\
\hline $\mathrm{C} 18: 3$ & Linolenic Acid & - & - \\
\hline $\mathrm{C} 20: 0$ & Arachidic Acid & $0.43 \pm 0.04$ & $0.006 \pm 0.001$ \\
\hline \multirow[t]{2}{*}{$\mathrm{C} 20: 1$} & Eicosenoic acid (11-cis) & $0.18 \pm 0.03$ & $0.003 \pm 0.001$ \\
\hline & total & 100 & $1.50 \pm 0.088$ \\
\hline
\end{tabular}


conditions of EN 1785; the signal to noise ratio $\mathrm{S} / \mathrm{N}>3$, and relative peak intensity at selective ion $m / z$ 98 to $m / z 112$. In the scan mode of GC-MS, the molecular ion $m / z 238$ of 2 -dDCB, $m / z 266$ of 2 -tDCB, $m / z 264$ of 2 -tDeCB were observed in $1 \mathrm{kGy}$-irradiated $\mathrm{A}$. In all 2ACBs focused in the present study, the ion $m / z 98$ was the base ion peak, and the relative intensities of ions $m / z 98$ to 112 were compared with standards with MS spectra that were practically the same in the detected range of $m / z 50$ to 300 (data not shown).

Thus, using GC-MS analysis, we confirmed the qualitative and quantitative presence of 2- $\mathrm{dDCB}, 2-$ $\mathrm{tDCB}$ and 2-tDeCB in $1 \mathrm{kGy}$-irradiated cashew nut.

Quantification of 2-dDCB, 2-tDCB and 2-tDeCB

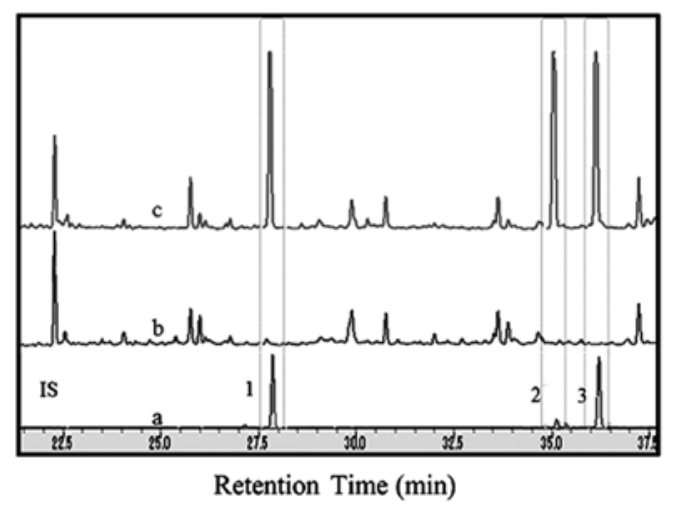

Fig. 1 GC-MS chromatograms of non-irradiated and $1 \mathrm{kGy}$-irradiated lot A cashew nut at $m / z 98$. (a), $0.08 \mu \mathrm{g} / \mathrm{mL}$ standard solutions for 2-dDCB, 2-tDeCB and 2-tDCB; (b), non-irradiated A sample (control); (c), $1 \mathrm{kGy}$-irradiated A after 1 day of irradiation; Peak labels: IS; Internal Itandard, 1 , 2-dDCB; 2, 2-tDeCB; 3, 2-tDCB. in lot A irradiated at 1, 5, $10 \mathrm{kGy}$ was carried out after 1 day of storage (Table 2). The concentrations of 2$\mathrm{dDCB}, 2-\mathrm{tDCB}$, and 2-tDeCB were found to increase with increasing radiation dose, demonstrating a linear relationship from 2.5 to $10 \mathrm{kGy}$. The coefficients of correlation $(r)$ for 2-dDCB, 2-tDCB, and 2-tDeCB were $0.978,0.977$, and 0.074 , respectively. From the slope of the each regression curves, the radio production yields of 2-ACBs (nmole) from precursor fatty acids (FA; mmole) at $1 \mathrm{kGy}$ irradiation were calculated. For dDCB, $0.043 \mu \mathrm{g} / \mathrm{g}$ cashew nut FW/kGy was produced. In Table 1 , the content of palmitic acid, precursor of $2-\mathrm{dDCB}$, was determined to be $0.14 \mathrm{mmole} / \mathrm{g}$ $\mathrm{FW}$, therefore, the yield of 2-dDCB was calculated to be $1.3 \mathrm{nmole} / \mathrm{mmole} \mathrm{FA} / \mathrm{kGy}$. The yield of 2 -tDCB

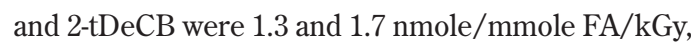
respectively. Therefore, the radioproduction yield for each 2-ACBs were almost at the same level. It is concluded that the content of each 2-ACB is depend on the fatty acid content in cashew nuts and irradiation dose, regardless of 2-ACB species. Ndiaye et al. reported that the radioproduction yield of 2-alkylcyclobutanones (nmol/mmol precursor fatty acid/kGy) in various foodstuffs, including cheese sardine trout beef chicken Mango (kernel), were the range between 1.0 to 1.6, and do not seem to depend on the nature of the food matrix ${ }^{17}$. The yield obtained in the present study for cashew nuts are the consistent level with those for other foodstuffs.

\section{Detection of 2-ACBs in non-irradiated cashew nut}

To provide accurate and reliable information on

Table 2 Concentrations of 2-ACBs in gamma-irradiated cashew nuts at $20^{\circ} \mathrm{C}$ (Lot A)

\begin{tabular}{llccccc}
\hline \multirow{2}{*}{ 2-ACBs } & \multicolumn{4}{c}{ Dose $(\mathrm{kGy})$} & \multirow{2}{*}{$\begin{array}{c}\text { Regression equation and } \\
\text { coefficient }\end{array}$} \\
\cline { 2 - 5 } & 0 & 1 & 5 & 10 & & ( \\
\hline 2-dDCB & $\mathrm{ND}^{2}$ & $0.047 \pm 0.003^{3}$ & $0.213 \pm 0.014$ & $0.434 \pm 0.045$ & $\mathrm{y}=0.0433 \mathrm{x}$ & $\mathrm{R}^{2}=0.9789$ \\
2-tDCB & $\mathrm{ND}$ & $0.048 \pm 0.005$ & $0.211 \pm 0.016$ & $0.412 \pm 0.043$ & $\mathrm{y}=0.0414 \mathrm{x}$ & $\mathrm{R}^{2}=0.9771$ \\
2-tDeCB & $\mathrm{ND}$ & $0.478 \pm 0.047$ & $2.10 \pm 0.19$ & $4.51 \pm 0.49$ & $\mathrm{y}=0.446 \mathrm{x}$ & $\mathrm{R}^{2}=0.9743$ \\
\hline
\end{tabular}

1. $\mathrm{x}$ : irradiation dose $(\mathrm{kGy}), \mathrm{y}: 2-\mathrm{ACB}$ content $(\mu \mathrm{g} / \mathrm{g} \mathrm{Fw})$

2. Not Detected

3. mean value + standard deviation $(n=4)$ 
the existence of 2-ACBs in non-irradiated samples, we subjected 2 lots of cashew nut to GC-HRMS. The limit of detection of GC-HRMS was examined using the solvent standard solution ( $n$-hexane). The signals to $n$-hexane background noise ratio above 3 were consistently obtained for both $m / z 98.073$ and 112.088 ions for $0.002 \mu \mathrm{g} / \mathrm{mL} 2-\mathrm{dDCB}$ and 2 -tDCB and for $0.008 \mu \mathrm{g} / \mathrm{mL} 2$-tDeCB. We supposed that 2 -ACB concentrations of at least 3 to 6 times more could be detected in the matrix sample solution with GC-HRMS. Therefore, 2- $\mathrm{dDCB}$ and 2-tDCB were spiked into the 2 lots of cashew nut at concentrations of 0.004 and $0.008 \mu \mathrm{g} / \mathrm{g}$ FW cashew nuts, and the expected final concentrations were 0.006 and $0.012 \mu \mathrm{g} / \mathrm{mL}$, respectively. And, 2-tDeCB were spiked at concentrations of
0.017 and $0.034 \mu \mathrm{g} / \mathrm{g}$ FW cashew nuts, the expected final concentrations were 0.025 and $0.05 \mu \mathrm{g} / \mathrm{mL}$, respectively. Then, these spiked samples and control samples were subjected to analysis simultaneously.

Fig. 2 shows the $m / z 98.073$ and 112.088 GCHRMS chromatograms of the control and spiked samples around retention time for $2-\mathrm{dDCB}$. The typical chromatogram of 2-dDCB in standard solution was illustrated with peaks at $23.29 \mathrm{~min}$ (a). Peaks were observed around the retention time in the sample spiked with $0.004 \mu \mathrm{g} / \mathrm{g}$ of 2 -dDCB (c) (e), but no significant peaks were found at the control sample retention time of 2-DCB (b) (d). In the spiked samples, the relationship of ion intensities between $\mathrm{m} / z 98.073$ and 112.088 was checked for the identification. The peak area
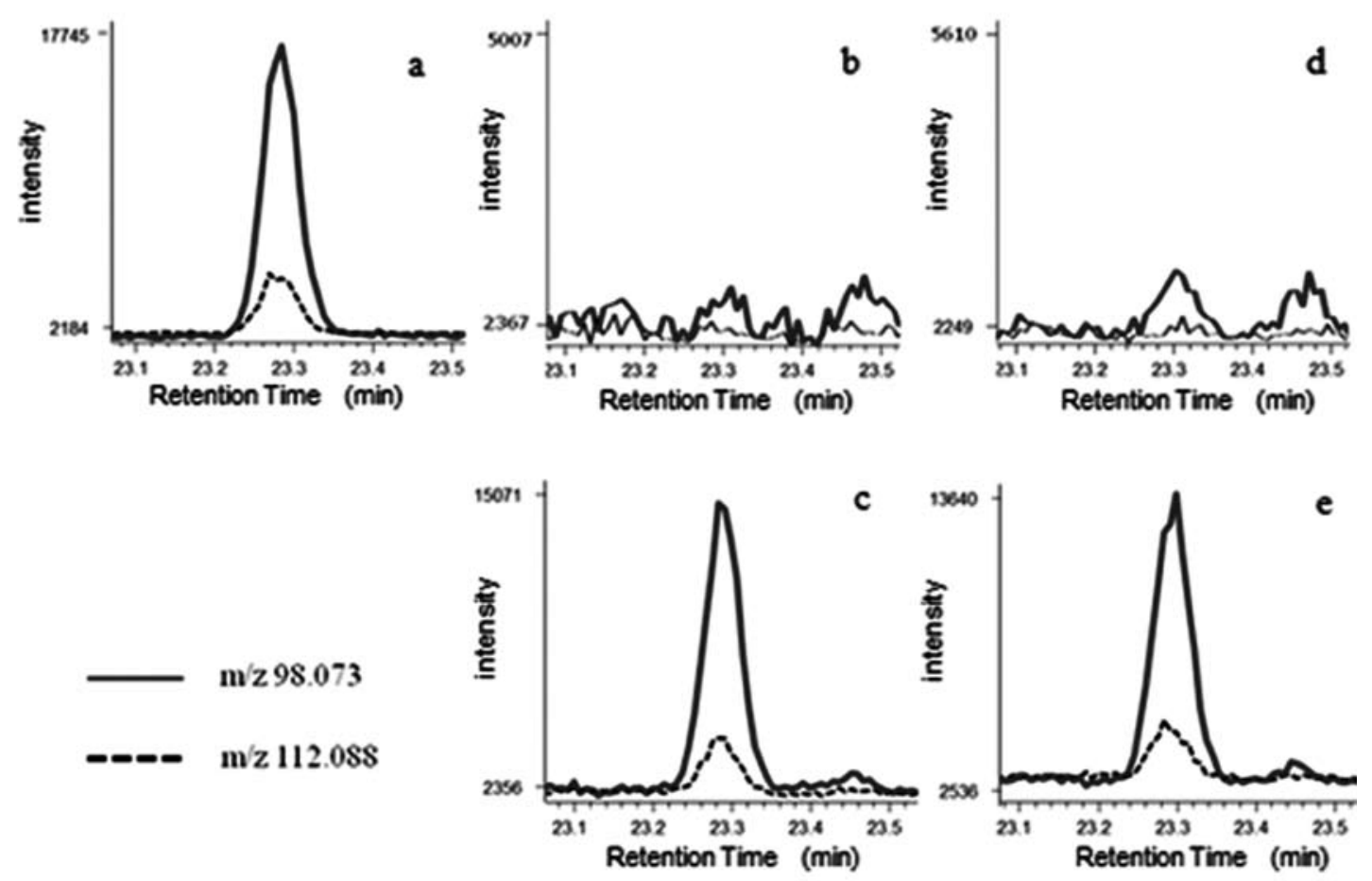

Fig. 2 GC-HRMS chromatograms of non-irradiated cashew nut confirming the absence of 2-dDCB at $m / z$ 98.073 and 112.088 .

(a), $0.006-\mu \mathrm{g} / \mathrm{mL}$ standard solution of 2-dDCB; (b), non-irradiated cashew nut sample (control) Lot A; (c), nonirradiated cashew nut (Lot A) spiked with $0.004 \mu \mathrm{g} / \mathrm{g}$ 2-dDCB; (d), non-irradiated cashew nut sample (control) Lot B; (e), non-irradiated cashew nut (Lot B) spiked with $0.004 \mu \mathrm{g} / \mathrm{g}$ 2-dDCB; Chromatograms: $m / z$ 98.073, —; $m / z 112.088, \cdots$. 
ratios of $m / z 112.088$ to 98.073 for Lot A and Lot B were 18.2 and 19.9 for LotB, respectively, these were within $\pm 20 \%$ of that of $0.01 \mu \mathrm{g} / \mathrm{mL}$ standard 2 -dDCB solution and the retention times were the same as standard solution. Therefore the the peaks would be identified as 2-dDCB.

Fig. 3 shows the $m / z 98.073$ and 112.088 GCHRMS chromatograms of the control and spiked samples around retention time for 2 -tDCB. And, the typical chromatogram of 2-tDCB in standard solution was illustrated with peaks at $30.81 \mathrm{~min}$ (a). Peaks with the difference of retention time at $+0.01 \mathrm{~min}$ were observed in the samples spiked with $0.008 \mu \mathrm{g} / \mathrm{g}$ of 2 -tDCB (c) and (e), and the relative ion intensities of $m / z 98.073$ and 112.088 were within $20 \%$ of those of
2-tDCB standard solution. However, no significant peaks $(\mathrm{S} / \mathrm{N}>3)$ were found at the control sample retention time of 2-DCB (b) and (d).

Similarly, Fig. 4 shows the $m / z 98.073,95.086$ and 112.088 GC-HRMS chromatograms of the control and spiked samples around retention time for 2 -tDeCB. For, 2-tDeCB, the typical chromatogram of 2-tDeCB in standard solution was illustrated with peaks at 29.81 min (a). Peaks within $+/-0.01$ min were observed in the samples spiked with $0.034 \mu \mathrm{g} / \mathrm{g}$ of 2 -tDeCB (c) and (e), and the relative ion intensities of $m / z 98.073$ and 112.088 were within $20 \%$ of those of 2 -tDeCB standard solution. However, no significant peaks $(\mathrm{S} / \mathrm{N}>3)$ were found in the control samples around retention time of 2-DCB (b) and (d) at $m / z 98.073$.
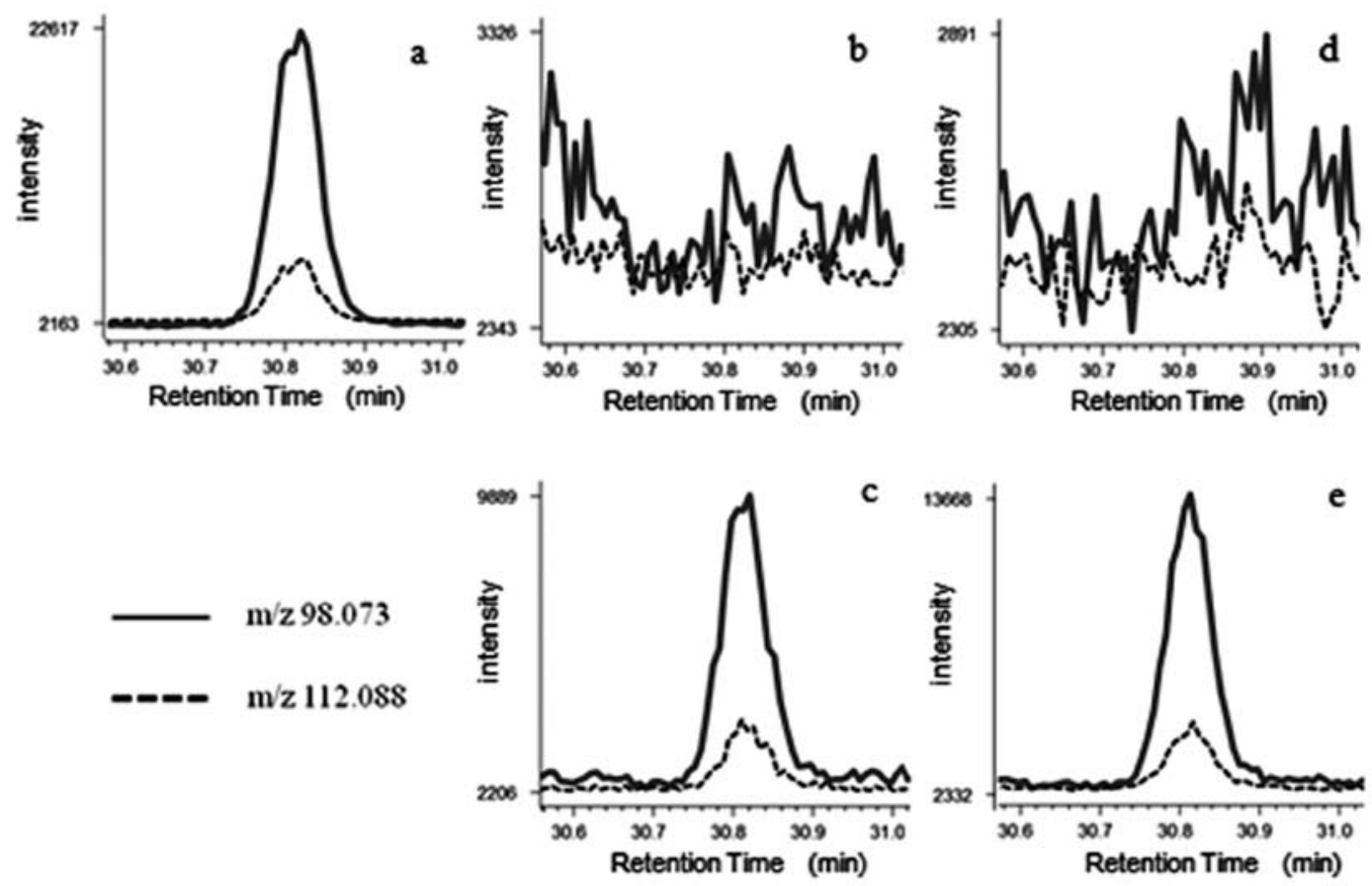

Fig. 3 GC-HRMS chromatograms of non-irradiated cashew nut confirming the absence of 2-tDCB at $m / z$ 98.073 and 112.088 .

(a), $0.012-\mu \mathrm{g} / \mathrm{mL}$ standard solution of 2-tDCB; (b), non-irradiated cashew nut sample (control) Lot A; (c), nonirradiated cashew nut (Lot A) spiked with $0.008 \mu \mathrm{g} / \mathrm{g} 2$-tDCB; (d), non-irradiated cashew nut sample (control) Lot B; (e), non-irradiated cashew nut (Lot B) spiked with $0.008 \mu \mathrm{g} / \mathrm{g}$ 2-tDCB; Chromatograms: $m / z$ 98.073, —; $m / z 112.088, \cdots$. 

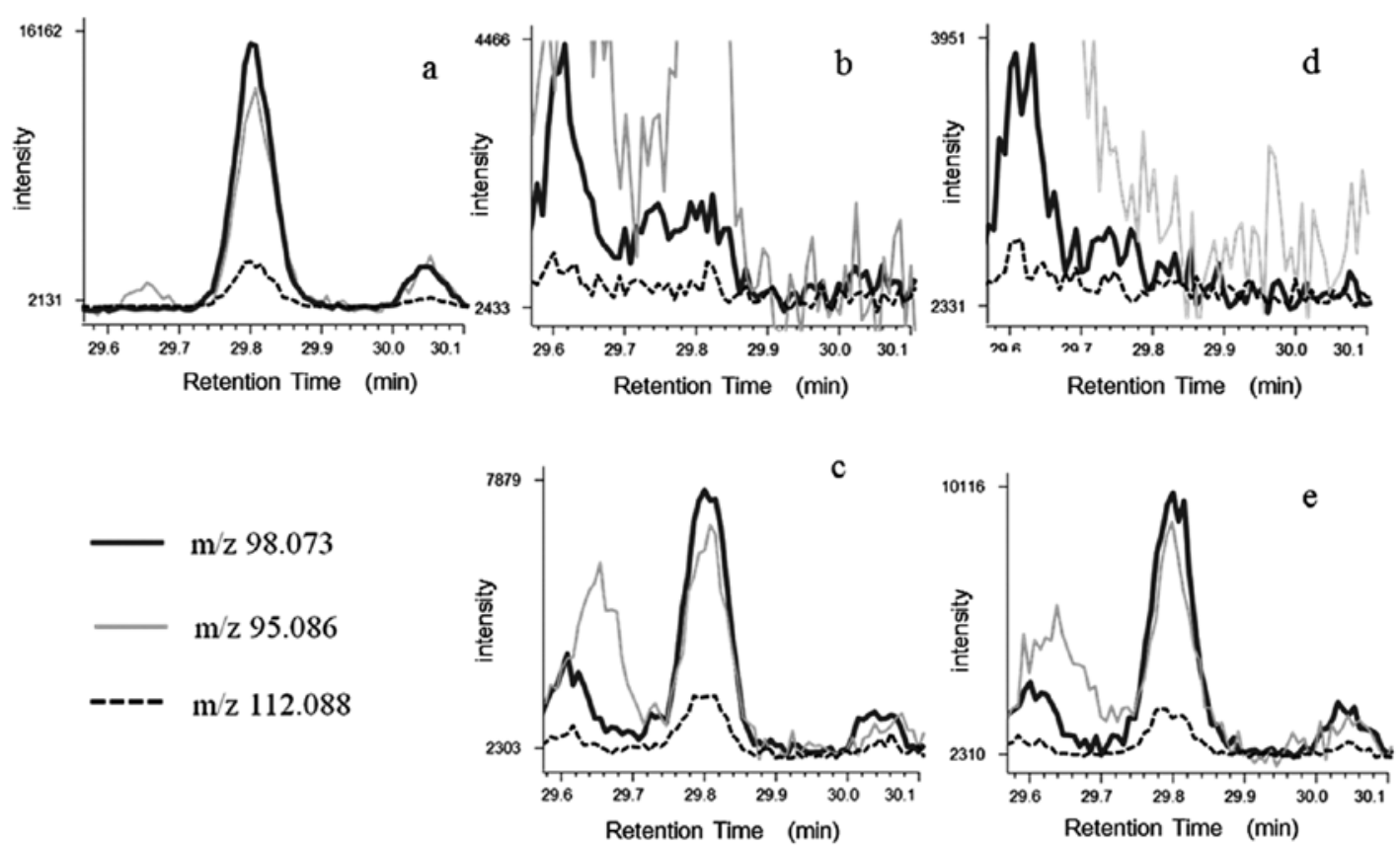

Fig. 4 GC-HRMS chromatograms of non-irradiated cashew nut confirming the absence of 2 -tDeCB at $\mathrm{m} / z$ 98.073 and 112.088 .

(a), $0.05-\mu \mathrm{g} / \mathrm{mL}$ standard solution of 2-tDeCB; (b), non-irradiated cashew nut sample (control) Lot A; (c), nonirradiated cashew nut (Lot A) spiked with $0.034 \mu \mathrm{g} / \mathrm{g} 2$-tDeCB; (d), non-irradiated cashew nut sample (control) Lot B; (e), non-irradiated cashew nut (Lot B) spiked with $0.034 \mu \mathrm{g} / \mathrm{g} 2$-tDeCB; Chromatograms: $m / z$ 98.073, —; $m / z 112.088, \cdots . m / z 95.086$, , -

These results indicated that $2-\mathrm{dDCB}, 2-\mathrm{tDCB}$ and 2 -tDeCB were less than detectable levels in all of the non-irradiated cashew nut samples in the present study, and 2-dDCB, 2-tDCB and 2-tDeCB were detected in samples spiked at 0.004, 0.008 and $0.034 \mu \mathrm{g} / \mathrm{g}$ FW under the same analytical conditions. In contrast, Variyar et al. reported the natural occurrence of 2$\mathrm{dDCB}$ and 2-tDCB and 2-tDeCB at concentrations of $2.70 \pm 1.71,1.0 \pm 0.08$, and $0.52 \pm 0.01 \mu \mathrm{g} / \mathrm{g}$, respectively, in commercial non-irradiated cashew nut samples. And the concentrations of 2- $\mathrm{dDCB}$ and 2tDCB and 2-tDeCB for $1 \mathrm{kGy}$ - irradiated cashew nut were $6.12 \pm 0.82,2.06 \pm 0.4$ and $0.8 \pm 0.1$, production of 2-dDCB was dominant regardless of fatty acid composition ${ }^{11}$. However, the lowest detectable levels found in the present study were quite lower than the natural levels in the previous report, and these results strongly support that 2-ACBs could be employed as markers for irradiated cashew nut samples.

\section{Conclusions}

2-ACBs were found only in irradiated cashew nut samples, and their amount increased proportionally with an increase in the irradiation dose. The production yields by irradiation at room temperature were calculated 1.3 to $1.7 \mathrm{nmole} / \mathrm{mmole}$ precursor fatty acid at $1 \mathrm{kGy}$. However, none of 2-dDCB, 2-tDCB nor 2 -tDeCB was observed in any of the non-irradiated cashew samples subjected.

\section{Acknowledgement}

This work was supported by grants-in-aid from 
the Food Safety Commission of Japan (No. 0906).

\section{Abbreviations}

2-ACB, 2-Alkylcyclobutanone; 2-CHCH, 2-Cyclohexylcyclohexanone; 2-dDCB, 2-dodecylcyclobutanone; EI, electron ionization; EN, European Norm; FA, Fatty Acid; FW, fresh weight; GC, Gas chromatograph; GC-MS, gas chromatography-mass spectrometry; GC-HRMS, high resolution gas chromatography mass spectrometer; IS, internal standard; LOD, limit of detection; SFE, Supercritical Fluid Extraction; SIM, selected-ion monitoring; SPE, solid-phase extraction; $\mathrm{S} / \mathrm{N}$, signal to noise; 2-tDCB, 2-tetradecylcyclobutanone; 2-tDeCB, 2-tetradecenylcyclobutanone; URP, unique radiolytic product.

\section{References}

1 ) Stevenson, M. H. et al. Irradiation detection. $\mathrm{Na}$ ture. 344(6263), p.202-203 (1990).

2 ) Boyd, D. R. et al. Synthesis, characterization, and potential use of 2-dodecylcyclobutanone as a marker for irradiated chicken. Journal of $\mathrm{Ag}$ ricultural and Food Chemistry. 39(4), p.789-792 (1991).

3 ) Zanardi, E. et al. Evaluation of 2-alkylcyclobutanones in irradiated cured pork products during vacuum-packed storage. Journal of Agricultural and Food Chemistry. 55(10), p.4264-4270 (2007).

4 ) Schreiber, G. A. et al. Intercomparisons to evaluate the suitability of gas-chromatographic, electron-spin-resonance spectrometric and thermoluminescence methods to detect irradiated foods in routine control. Radiation Physics and Chemistry. 42(1-3), p.391-396 (1993).

5 ) Rahman, R. et al. A rapid method (SFE-TLC) for the identification of irradiated chicken. Food Research International. 29(3-4), p.301-307 (1996).

6 ) Crone, A. V. J. et al. Synthesis, characterization, and use of 2-tetradecylcyclobutanone together with other cyclobutanones as markers for irradiated liquid whole egg. Journal of the Science of Food and Agriculture. 62 (4), p.361-367 (1993).

7 ) Sin, D. W. et al. Application of pentafluorophe- nyl hydrazine on detecting 2-dodecylcyclobutanone and 2-tetradecylcyclobutanone in irradiated chicken, pork and mangoes by gas chromatography-mass spectrometry. European Food Research and Technology. 222(5-6), p.674-680 (2006).

8 ) Stewart, E. M. et al. 2-Alkylcyclobutanones as markers for the detection of irradiated mango, papaya, camembert cheese and salmon meat. Journal of the Science of Food and Agriculture. 80(1), p.121-130 (2000).

9 ) Tanabe, Hiroko; Goto, Michiko. Consideration on detection of irradiated rainbow trout by ESR method and 2-alkylcyclobutanone analysis. Food Irradiation Japan. 37, p.17-23 (2002).

10) Variyar, P. S. et al. Natural existence of 2-alkylcyclobutanones. Journal of Agricultural and Food Chemistry. 56(24), p.11817-11823 (2008).

11) Crewsa, C. et al. Analysis of 2-alkylcyclobutanones for detection of food irradiation: Current status, needs and prospects. Journal of Food Composition and Analysis. 26(1-2), p.1-11 (2012).

12) Chen, Susu et al. Identification of 2-alkylcyclobutanones in nutmeg (myristica fragrans). Food Chemisty. 134(1), p.359-365 (2012).

13) Todoriki, Setsuko et al. Effects of gamma-irradiation on lipid metabolic changes of potato tubers in response to mechanical injury. Boiscience Boitechnology and Biochemistry. 56, p.1991-1994 (1992).

14) Todoriki, Setsuko. Effects of gamma-irradiation on the activity of tonoplast H+ATPase from potato tubers (solanum tuberosumL.). Plant and Cell Physiology. 35, p.829-836 (1994).

15) Numata, Masahiko et al. Preparation of sulfoxide residue bonded silica stationary phase for separation of polychlorinated biphenyls from mineral oils. Analytical Chemistry. 79, p.9211-9217 (2007).

16) Chen, Susu et al. Identification of irradiated prawn (penaeus monodon) using thermoluminescence and 2-alkylcyclobutanone analyses. Journal of Agricultural and Food Chemistry. 59(1), p.78-84 (2011). 
17) Ndiaye, B. et al. 2-Alkylcyclobutanones as markers for irradiated foodstuffs II. The CEN (European Committee for Standardization) method: field of application and limit of utilization. Radiation Physics and Chemistry. 55(4), p.437-445 (1999).

\section{和文要旨}

近年, 天然のカシューナッツ中の 2-アルキルシ クロブタノン類（2-ドデシルシクロブタノン， 2テトラデシルシクロブタノン， 2-テトラでセニルシ クロブタノン）の存在が報告されている。本研究で は超臨界流体抽出により, 市販カシューナッツ試 料から，2-アルキルシクロブタノン類を抽出し，高 分解能ガスクロマトグラフ質量分析計により検出
を行ったが，非照射試料から 2-アルキルシクロブ タノン類を検出することはできなかった。一方，1 $\mathrm{kGy}$ 以上の照射試料では，2-ドデシルシクロブタノ ン，2-テトラデシルシクロブタノン，2-テトラでセ ニルシクロブタノンが検出された。照射による線量 $1 \mathrm{kGy}$ あたりの 2-ACB の生成効率, nmole/mmole 親脂肪酸/ $\mathrm{kGy}$ は，2-dDCB ; 1.3, 2-tDCB ; 1.3 および 2-tDeCB；1.7であった。

キーワード:食品照射，2-アルキルシクロブタノン， カシューナッツ, 検知法, 高分解能ガスクロマトグ ラフ質量分析計

(2012 年 8 月 1 日受理) 